By LOUIS SHORES

\title{
Evaluating Library Service to Higher Education
}

Louis Shores is director of the Library School of George Peabody College for Teachers. He is also chairman of the A.L.A. Subcommittee on Budgets, Compensation, and Schemes of Service for Libraries Connected with Universities, Colleges, and Teacher Training Institutions.

S INCE June, 1939, a Committee of the $\bigcirc$ A.C.R.L. on Budgets, Compensation, and Schemes of Service has been working with a subcommittee of the A.L.A. Board on Salaries, Staff, and Tenure, on the problem of evaluating certain aspects of library service to higher education. As originally conceived, the task of this joint committee was to bring up to date the Brown report ${ }^{1}$ and to integrate the result with such recommendations as are found in Classification and Pay Plans for $\mathbf{M u}$ nicipal Public Libraries, ${ }^{2}$ and as are likely to be incorporated in comparable subsequent undertakings for school and special libraries. Thus ultimately the object is to provide a unified set of personnel and budget standards for the library profession as a whole.

As the work of this joint committee progressed, it became increasingly evident that personnel and budget could not be

\footnotetext{
${ }^{1}$ Budgets, Classification and Compensation Plans for University and College Libraries . . A.L.A., ${ }^{1929 .}$ Classification and Pay Plans for Municipal Public Libraries. A.L.A., 1938 .
}

considered independently of other aspects of library service such as book stock, building, and educational integration. That this was the experience of both the Brown subcommittee and the A.L.A. Board on Salaries, Staff, and Tenure, is evident in their finished reports. The Brown plans, for example, include not only personnel specifications but budget allocations for books, periodicals, and bindings. The A.L.A. Classification and Pay Plans for Municipal Public Libraries presents a score card which includes in addition to staff and budget such items as book collection, circulation, hours open, departmental and branch organization.

There were, besides, other reasons why the joint committee felt it desirable to broaden its undertaking. Several higher educational accrediting agencies; notably the American Association of Junior Colleges, the American Association of Teachers Colleges, and the Southern Association of Colleges and Secondary Schools were seeking to develop criteria for evaluating libraries as well as other units in American higher education. The libraries of medical, law, engineering, music, agriculture, and other professional schools attached to or associated with institutions of higher education, expressed a desire to work with or be included in the committee's undertaking.

In view of these and other considera- 
tions, such as the opinion expressed by librarians and college presidents in connection with the job analysis and the first $\mathrm{draft}^{3}$ prepared by this committee, the following revised statement of aims and procedure was submitted to the A.C.R.L. board.

As the joint committee sees its task, the broad purpose is "To develop criteria for evaluating libraries of higher educational institutions with adequate recognition of the varying objectives of these institutions."

Toward the realization of this aim, the committee has prepared or is preparing:

I. A method by which a library may compile for itself its service load

2. A job analysis of the staff needs of libraries of each type and size

3. A classification of positions in various types and sizes of libraries

4. A practical rating scale by means of which any educational institution or accrediting agency (or the library itself) may determine to what degree a specific library measures up to the criteria suggested

\section{Procedure}

As a first step the joint committee reviewed rather carefully the literature relating to standards for libraries in higher educational institutions. It found that at various times both educators and librarians favored different types and sets of criteria for evaluating libraries. In the early days heavy emphasis was placed on quantitative statements applied especially to book stock and budget. For the former a total number of 8000 volumes- 1000 for each of the eight so-called essential departments-was first specified by the North Central Association. Later this

Classification and Pay Plans for Libraries in Junior Colleges, Four-year Colleges, Universities. and Teacher Training Institutions. A.L.A., I940. (Mimeographed rough draft) figure was raised successively by various individuals until it reached the round number of $100,000^{4}$ volumes, when a reaction set in and emphasis was shifted to selection and relation to the educational program.

The budget criterion also has undergone considerable development. Time was when library costs were computed on a $\$ 25$ per student basis. Then someone suggested that perhaps faculty members constituted a more important part of the population to be served, and consequently, it was proposed that the library budget be fixed as a certain per cent of the total educational budget, usually 4 per cent. The Brown report utilized both the per student and the per cent of total educational budget criteria and in addition specified a minimum expenditure of $\$ 10,000$ annually for institutions in class three, the lowest class listed.

\section{Efforts toward Adequate Standards}

In I932, the Advisory Group on College Libraries of the Carnegie Corporation issued a set of qualitative standards ${ }^{5}$ which avoided all quantitative specifications and described adequate library service in general statements. Two years later the North Central's famous patterns ${ }^{6}$ appeared likewise defining adequate library service somewhat generally and leaving the final judgment to the institution concerned or to the individual responsible for interpreting the application of the qualitative standards.

All of these efforts to develop a measure of library excellence and many more, the

\footnotetext{
4 Bishop, W. W. The Backs of Books. Williams \& Wilkins, 1926. pp. 202-25.

- Carnegie Corporation of New York. College Library Standards Adopted by the Advisory Group on College Libraries. 1932.

B North Central Assn. of Colleges and Secondary Schools. Commission on Institutions of Higher Education. Manual of Accrediting Procedures. University of Chicago Press, 1934.
} 
joint committee studied, discussed, applied. And then it turned to college and university librarians, presidents, officers of accrediting agencies and foundations. Hundreds of letters were sent and received, the opinions sifted, weighed, and incorporated wherever possible. Next, the libraries themselves were studied through A.L.A. and U.S. Office of Education statistics, the exhibits found in the recently released Eells ${ }^{7}$ and Marsh ${ }^{8}$ volumes, individual institutional annual reports and manuals of procedure, and finally through a two-week job analysis conducted with the cooperation of some thirty libraries of all types and in all regions.

Finally in March, 1940, a first rough draft of the section on classes of libraries was issued and distributed to cooperating libraries. Both an open general meeting and several small meetings with librarians of professional medical, engineering, law, and agricultural libraries, were held in Cincinnati, and as a result of the criticisms and suggestions received there and through correspondence with college presidents, a second draft was begun. It is this second draft, now nearing completion and possibly to be presented in Boston, that is under consideration here.

\section{Result of Canvass}

At the outset I should like to indicate briefly the result of the committee's canvass of library and educational opinion. There was general agreement on the need for revised standards, but a wide range of opinion on the essential elements of valid and reliable criteria. Perhaps the greatest differences were expressed on the following questions:

${ }^{7}$ Eells, W. C. American Junior Colleges. American Council on Education, I 940 , pp. I I $9 \cdot 484$. leges. American Council on Education, 1940, pp. leges. A
r67-ior 8 .

JUNE, 1941

\section{Quantitative versus qualitative stand-} ards. Those who favored the former pointed out the intangible nature of the latter, the resulting varying interpretation of adequacy, inability frequently to secure the high type of competence necessary to apply such standards. Those who favored the latter concentrated on the injustice of mere number of volumes, size of budget, amount of equipment in a particular situation where the library was eminently serving the educational needs of the program.

2. Too high versus too low. Those with generous library collections, equipment, and budgets, feared low standards might stimulate their presidents to seek library retrenchments. Those with inadequate collections, equipment, and budgets, feared the standards would be so high that their institutions would be discouraged from even trying.

3. Too detailed versus too general. About thirty college and university presidents were asked to comment on the general summary chart. Invariably they observed that detailed specifications would be necessary for these weightings to mean anything at all. A like number of librarians, asked to examine the detailed criteria, expressed fear that "they might break down of their own weight."

4. Science versus art. Those statistically inclined generally sought a scientific basis for nearly every committee move. A number of the presidents reacted violently to any application of the method of physical sciences to anything as intangible as adequate library service.

\section{Assumptions}

The committee has proceeded on the assumption that its responsibility involves libraries of all types of higher educational 
institutions-(a) junior colleges, normal schools, and other non-degree-conferring institutions above the high school level; (b) liberal arts colleges, four-year teachertraining colleges, technical schools, and other degree-conferring institutions largely on the undergraduate level; (c) universities and other institutions with major graduate instructional programs.

A further assumption is that the following six criteria, not necessarily in order of importance, determine largely the adequacy of library service: I. budget, 2 . personnel, 3. book stock, 4. quarters and equipment, 5. organization, and 6 . educational participation. These six criteria are represented in the rating chart summary tentatively weighted with the aid of librarians and educators throughout the country. Because at present the detailed weightings are still in process of determination, I can only indicate that out of one thousand points, 300 have been assigned to quantitative and qualitative aspects of the present collection and the annual expenditure for books during the last five years. Another 300 points have been assigned to personnel, including duties, compensation, number, qualifications, etc. The remaining 400 points are divided equally between quarters and equipment, and organization and educational participation.

It must be emphasized, however, that this summary is still highly tentative. Even among members of the committee, there are some who feel that the building is still weighted too heavily, the service inadequately, and the number of points under book stock are not distributed proportionately.

\section{Service Load}

At the outset the committee recognized the desirability of flexible standards to fit the varying needs, size, and educational aims of the institutions to be measured. Accordingly, the idea of a service load was born. This idea began with the simple plan of counting the number of students to be served. It was at once apparent, however, that a junior college of 5000 students and a university of 5000 students required completely different library facilities; that two liberal arts colleges, one with a number of graduate and honors students and a faculty heavily engaged in research required quite different facilities from those desirable in another college engaged almost entirely in undergraduate instruction.

Accordingly, after a careful study of the vital statistics of representative higher educational libraries of all types and in all regions, the following formula for determining service load was devised:

Count each undergraduate under-class student-one unit

Count each undergraduate upper-class student-two units

Count each undergraduate honors studentthree units

Count each graduate student-four units

Count each faculty member-five units

Thus, a liberal arts college with 300 under class, 200 upper class, 50 honors, 25 graduate students, and 50 faculty members would have a library service load of I 200 service units. At present the Association of College Registrars' definition of full time student is accepted and the librarian is permitted to define faculty member as his institution does.

\section{Book Stock, Budget, Hours Open}

On this basis the committee was able to develop flexible quantitative standards for present book stock, budget, and the num- 
ber of hours a library was to remain open. For example, for book stock, the following quantitative standards have been proposed:

\section{Exhibit A. Quantitative Standing of Book Stock}

Your Library Has If It Serves an Institution That Is

\begin{tabular}{|c|c|c|}
\hline $\begin{array}{l}\text { 2- or } 3-\text { year } \\
\text { degree }\end{array}$ & $\begin{array}{l}\text { 4-year degree- } \\
\text { conferring (not } \\
\text { emphasizing grad- } \\
\text { uate work) }\end{array}$ & $\begin{array}{l}\text { University (with } \\
\text { graduate and pro- } \\
\text { fessional school } \\
\text { emphasis) }\end{array}$ \\
\hline $\begin{array}{l}50 \text { books per unit } \\
\text { for first roo units } \\
\text { (but in no case } \\
\text { less than } 5000 \\
\text { volumes) }\end{array}$ & $\begin{array}{l}\text { 5o books per unit } \\
\text { for first } 800 \text { units } \\
\text { (In no case less } \\
\text { than } 30, \infty 00 \text { vol- } \\
\text { umes) }\end{array}$ & $\begin{array}{l}70 \text { books per unit } \\
\text { for first } 2000 \text {. (In } \\
\text { no case less than } \\
200,000 \text { volumes) }\end{array}$ \\
\hline $\begin{array}{l}\text { Io vols. per unit } \\
\text { for next } 600\end{array}$ & $\begin{array}{l}30 \text { vols. per unit } \\
\text { for next } 700\end{array}$ & $\begin{array}{l}4^{\circ} \text { vols. per unit } \\
\text { for next } 2000\end{array}$ \\
\hline $\begin{array}{l}8 \text { vols. per unit } \\
\text { for next } 500\end{array}$ & $\begin{array}{l}20 \text { vols. per unit } \\
\text { for next I } 500\end{array}$ & $\begin{array}{l}30 \text { vols. per unit } \\
\text { over } 4000\end{array}$ \\
\hline $\begin{array}{l}5 \text { vols. per unit } \\
\text { over } 1200\end{array}$ & $\begin{array}{l}\text { ro vols. per unit } \\
\text { for over } 3000\end{array}$ & \\
\hline
\end{tabular}

Likewise, on the same service load basis, the following budget plan for books, salaries, and supplies has been developed although the actual figures are still highly tentative.

\section{Exhibit B. Budgets for Books, Salaries, Supplies}

\begin{tabular}{|c|c|c|c|}
\hline $\begin{array}{l}\text { The library spends } \\
\text { each year }\end{array}$ & $\begin{array}{l}\text { For } \\
\text { Books, }\end{array}$ & $\begin{array}{l}\text { For } \\
\text { Salaries }\end{array}$ & $\begin{array}{l}\text { For } \\
\text { Supplies, }\end{array}$ \\
\hline $\begin{array}{l}\text { For each unit } \\
\text { first } 2000 \ldots \ldots\end{array}$ & $\$ 7$ & $\$ 14$ & \\
\hline $\begin{array}{l}\text { For each unit o } \\
\text { second } 2000 \ldots \ldots\end{array}$ & 6 & I 2 & 2 \\
\hline $\begin{array}{l}\text { For each unit } \\
\text { third } 2000 \text {. } \\
\text { For each unit ove }\end{array}$ & 4 & 8 & I \\
\hline $6000 \ldots \ldots \ldots$ & 3 & 6 & .50 \\
\hline
\end{tabular}

Finally, for the number of hours the library should be open weekly, a graduated scale recommending 26 hours for libraries serving less than 200 units to 80 hours for a library serving more than 5000 units has been proposed.

\section{Qualitative Standards}

On the qualitative side the task has been more difficult and the progress slower. For example, the qualitative evaluation of the book stock has involved some rather interesting experiments with sample lists of reference and periodical titles. The idea behind these sample lists is very much the same as that behind statistical sampling. $\mathrm{We}$ are testing the assumption, for example, that it is not necessary to check a list of 800 to 4000 reference titles to determine whether a reference collection is adequate, if one has a carefully selected sample list of as few as 20 core titles for junior college libraries, 40 for liberal arts colleges, and 80 for university libraries. The presence of these key or sample titles, we believe, assures a fairly strong reference collection.

In other cases we have permitted the librarian and the faculty to evaluate their collection on a point basis from the standpoint of the institution's curricular, cocurricular, and research needs.

Finally, on the basis of a job analysis conducted in some thirty libraries of all types of institutions and in all regions, the committee is attempting to set up a classification and pay plan for workers in higher educational libraries that will contribute to both a quantitative and a qualitative evaluation of personnel.

The measurement of service presents many more difficulties. To date we have succeeded in measuring such aspects of organization as acquisitions, preparations, circulation, and less successfully, reference. We haven't, however, been able to reduce those intangible aspects of library adequacy, which for want of a better term, we call educational participation. For the most part this has meant to us, library instruction, stimulation of student reading, publicity, assistance in formulation of educational policies, etc.

One last problem has perplexed the committee-the need for regional adjust(Continued on page 236) 
rooms. For other areas the selection of the lighting system must meet the specific needs as outlined.

The selection of lighting systems and equipment for other than illumination purposes should always be secondary to the functional use of such equipment.

The attached bibliography has been selected to enable interested individuals to obtain a broader knowledge of the requirements of lighting for seeing.

\section{References}

Illuminating Engineering Society. American Recommended Practice of School Lighting. The Society. Feb. 17, 1938.

Luckiesh, M., and Moss, F. K. "Quality of Lighting." Illuminating Engineering
Society. Transactions 30:531-62, July 1935.

"Prescribing Light and Lighting." Illuminating Engineering Society Transactions 32:19-48, Jan. 1937.

- "Brightness-Contrast in Seeing." Illuminating Engineering Society. Transactions 34:571-97, June 1939.

Lancaster, W. B. "Illumination Levels and Eye Comfort Conditions." Illuminating Engineering Society. Transactions $33: 964-73$, Dec. 1938.

Harrison, Ward. "What Is Wrong with Our 5o-foot-candle Installations." Illuminating Engineering Society. Transactions 32:208-18, Feb. 1937.

Potter, W. M., and Darley, K. G. "The Design of Luminaires for Fluorescent Lamps." Illuminating Engineering $35: 759-85$. Nov. 1940 .

\section{Evaluating Library Service to Higher Education}

(Continued from page 215)

\section{Exhibit C. Library Classification}

\begin{tabular}{c|c|l}
\hline \hline $\begin{array}{c}\text { Libraries } \\
\text { of Class }\end{array}$ & Have a Rating of & \multicolumn{1}{|c}{ And Are } \\
\hline A & Over I800 points & $\begin{array}{l}\text { High for sections } \\
\text { high in resources }\end{array}$ \\
\hline B & I 500 to I800 points & $\begin{array}{l}\text { High for country as } \\
\text { a whole }\end{array}$ \\
\hline C & 1000 to 1500 points & $\begin{array}{l}\text { Minimum for ad- } \\
\text { vanced sections; } \\
\text { high for sections } \\
\text { low in resources }\end{array}$ \\
\hline D & 1000 points & $\begin{array}{l}\text { Minimum for coun- } \\
\text { try as a whole }\end{array}$ \\
\hline E & 800 to rooo points & $\begin{array}{l}\text { Minimum for sec- } \\
\text { tions low in re- } \\
\text { sources }\end{array}$ \\
\hline F & 600 to 800 points & $\begin{array}{l}\text { Substandard for ad- } \\
\text { vanced sections }\end{array}$ \\
\hline H & Beo to 600 points & $\begin{array}{l}\text { Below standard for } \\
\text { whole country }\end{array}$ \\
\hline Below 400 points & $\begin{array}{l}\text { Below standard for } \\
\text { sections low in re- } \\
\text { sources }\end{array}$ \\
\hline
\end{tabular}

ments. Standards considered too low among New England college libraries frequently proved too high for college

libraries in the South. Accordingly, a classification which would recognize a regional differential has been proposed which resembles very much the thermometer used by the Eells Committee in the Cooperative Secondary School Standards. Roughly, this plan might provide for eight classes of libraries as shown in the table to the left.

Perhaps some idea of the committee's work and problems has been presented. We are hopeful that the second draft of the committee's plan will be available in detail for criticism by the membership before Boston. In the meantime, we repeat our invitation to every member of the A.C.R.L. to contribute such ideas and suggestions as will advance the quest for an adequate measure of library service to institutions of higher education. 